\title{
Urticarial Reaction to Ustekinumab During the Treatment of Plaque Psoriasis in a Hepatitis C-Positive Patient
}

\author{
Christopher H. Chu ${ }^{1}$ (D) Charles Davis ${ }^{1,2}$
}

Published online: 4 July 2017

(c) The Author(s) 2017. This article is an open access publication

\begin{abstract}
A 62-year-old white woman with a history of hepatitis $\mathrm{C}$ and type 2 diabetes mellitus developed urticaria during treatment with ustekinumab for plaque psoriasis. The patient received two 45-mg ustekinumab injections in her first 2 months and then one 45-mg injection every 3 months for her psoriasis. After 10 months, she developed a round red rash on her skin diffusely on her body. She also complained of joint pain in her hands. Rheumatology became involved, and investigations revealed that her antinuclear antibody titer was negative, but her rheumatoid factor, erythrocyte sedimentation rate, and liver function enzymes were elevated. She was diagnosed with urticaria, and ustekinumab was discontinued. A Naranjo assessment score of 6 was obtained, indicating a probable relationship between the patient's urticaria and her use of ustekinumab. Ustekinumab was subsequently discontinued, and the patient received a course of Harvoni ${ }^{\circledR}$ (Gilead Sciences, Inc., Forest City, California, United States) (ledispasvir/sofosbuvir) with clearance of the hepatitis $\mathrm{C}$ virus. The patient is currently receiving another biologic agent,
\end{abstract}

Christopher H. Chu and Charles Davis provided equal contributions to the production of this article.

Christopher H. Chu

christopher.chu@uscmed.sc.edu

1 School of Medicine, University of South Carolina, 6311 Garners Ferry Road, Building \#3, Columbia, SC 29209, USA

2 Dorn VA Medical Center, Columbia, SC, USA ixekizumab, and reports no complaints, including that of urticaria.

\section{Key Points}

We report a patient who experienced an adverse drug reaction from injections of ustekinumab.

The patient was being treated for psoriasis but also had type 2 diabetes mellitus.

We suggest that this reaction was mediated by antiustekinumab antibodies and may be associated with her hepatitis C.

\section{Introduction}

Psoriasis is a chronic autoimmune disease characterized by patches of inflamed, itchy, and scaly skin. Methods of treatment involve topical corticosteroids and emollients for mild-to-moderate disease with progression to phototherapy and biologic agents for moderate-to-severe cases [1]. One such biologic agent is ustekinumab (Stelara ${ }^{\circledR}$ ), a human monoclonal antibody that targets interleukin (IL)-12 and IL23. The efficacy of ustekinumab has been well documented with randomized, double-blind, placebo-controlled studies showing a significant reduction in dermatologic symptoms after dosing in both 12- and 8-week intervals [2-4]. It has few side effects, such as respiratory infections, headache, tiredness, joint pain, itching, and vomiting [5]. Our report details a case of a cutaneous reaction to the medication. 


\section{Case Report}

A 62-year-old white woman with a history of hepatitis $\mathrm{C}$ and type 2 diabetes mellitus diagnosed with psoriasis in 1986 presented with a flare in her skin symptoms in July of 2013. The patient's hepatitis C viral typing and viral load in 2008 were type $1 \mathrm{~b}$ and $2,570,000 \mathrm{IU} / \mathrm{mL}$, respectively. The patient reported no allergies. Previous treatment with psoralen and ultraviolet $\mathrm{A}$, broadband and narrowband ultraviolet B, etanercept $\left(\right.$ Enbrel $\left.^{\circledR}\right)$, and cyclosporine were ineffective. Her most recent regimen was clobetasol and triamcinolone. However, her symptoms became refractory to treatment. Thus, ustekinumab (Stelara ${ }^{\circledR}$ ) was indicated. Her Psoriasis Area and Severity Index was 11.5 with a body surface area of approximately $30 \%$ at the time of prescription. Ustekinumab was approved in August 2013. Her first two doses of $45 \mathrm{mg}$ were injected subcutaneously in the following 2 months in September and October. The result of these doses was near-complete resolution of her skin plaques. Her only complaint was that of mild joint pain.

The patient's dosing schedule was increased to 3 months. Her joint symptoms, now particularly affecting her proximal interphalangeal joints, remained persistent despite the use of nonsteroidal anti-inflammatory drugs. In January 2014, the patient began seeing a rheumatologist; her antinuclear antibody titer was negative, but the rheumatoid factor, erythrocyte sedimentation rate, and liver function enzymes were elevated. Her rheumatoid factor was at $55.5 \mathrm{IU} / \mathrm{mL}$ with a reference range of $\leq 30$. Her erythrocyte sedimentation rate was at $45 \mathrm{~mm} / \mathrm{h}$ with a reference range of $0-15$. Alanine transaminase was at $73 \mathrm{U} / \mathrm{L}$ with a reference range of 0-55. Aspartate transaminase was at $82 \mathrm{U} / \mathrm{L}$ with a reference range of 5-34. Rheumatoid factor elevation is notably associated with hepatitis C [6].

Ustekinumab injections were continued for the remainder of 2014. The patient was briefly lost to follow-up, and injections began again in April 2015. In July 2015, the patient described an episode of urticaria lasting approximately 3-4 weeks following the injection. After another dose in January 2016, the patient once again developed urticaria. At this time, the Psoriasis Area and Severity Index and affected body surface area were 16.5 and $>50 \%$, respectively. Ustekinumab was subsequently discontinued, and the rash resolved.

A Naranjo assessment score of 6 was obtained, indicating a probable relationship between this patient's urticaria and the use of ustekinumab. Following the discontinuation of the medication, the patient began treatment for her hepatitis C with Harvoni ${ }^{\circledR}$ (Gilead Sciences, Inc., Forest City, California, United States) (ledispasvir $90 \mathrm{mg} /$ sofosbuvir $400 \mathrm{mg}$ ). In November 2016, the patient's viral load was undetectable, and the infection was presumed to be cleared. The patient began receiving a new course of a different biologic agent, ixekizumab in May 2017 and reports no complaints, including that of urticaria.

\section{Discussion}

Psoriasis is one of the most prevalent immune-mediated inflammatory diseases globally. Prevalence in USA is as high as $3.2 \%$ in adults over the age of 20 years and as high as $8.5 \%$ in Norway $[7,8]$. This disease primarily manifests as localized plaque psoriasis and dramatically affects the quality of life of patients.

The pathophysiology of psoriasis, in its simplest form, is the impaired differentiation of keratinocytes and rapid growth of the epidermal layer of the skin caused by inflammation [9]. Novel drugs have targeted certain components of this inflammatory cascade. One such drug is ustekinumab, a fully humanized IgG1k monoclonal antibody with high affinity to the p40 subunit shared by IL-12 and IL-23. This binding prevents subsequent interaction with the IL-12R $\beta 1$ receptor expressed on immune cells and neutralizing their inflammatory activity [5].

In some instances, adverse effects are reported by patients. The most frequently reported symptoms by patients are upper respiratory infections, headache, tiredness, and joint pain. Very rarely, approximately $<1 \%$ in patients with psoriasis and psoriatic arthritis, urticaria is reported [5]. Only six previous cases of urticaria have been found in the literature $[10,11]$. The patient in this report also has hepatitis $\mathrm{C}$, a disease long known to have multiple skin manifestations and is a significant cause of urticaria [12]. With regard to psoriasis, however, the literature is not in complete agreement with studies finding only its association with an anti-hepatitis C virus antibody [13-15].

Given the late presentation of urticaria in this patient following numerous doses of ustekinumab, it is possible that anti-ustekinumab antibodies were developed over the course of treatment. Such immunogenicity was found in $5.1 \%$ of patients in the placebo-controlled clinical trials of the drug with a predominantly low serum titer $[2,3]$. It is possible that sensitization occurred early in the treatment course; any antibodies formed then would contribute to her cutaneous reaction in subsequent medication doses.

However, treatment resources were directed at clearing the hepatitis $\mathrm{C}$ infection and providing an alternate biologic agent for the management of the patient's psoriasis. Though serum tests were not performed to confirm the presence of antibodies, we do still suggest that antibodies were produced to ustekinumab and contributed to her cutaneous manifestations. No such reactions were reported with the use of ixekizumab by the patient. 


\section{Conclusion}

We report a case of urticaria following the use of ustekinumab for the treatment of psoriasis in a patient with type 2 diabetes and hepatitis C. Ustekinumab was discontinued following the second episode of urticaria, and another biologic agent, ixekizumab, was given following treatment of the hepatitis $\mathrm{C}$ infection without any adverse effects, including urticaria. The production of anti-ustekinumab antibodies is presumed to have triggered the urticaria. Further studies are needed to fully discern the relationship between antibodies against ustekinumab and adverse reactions.

\section{Compliance with Ethical Standards}

Funding No sources of funding were received for the preparation of this article.

Conflict of interest Christopher H. Chu and Charles Davis have no conflicts of interest directly relevant to the content of this article.

Informed consent Written informed consent was obtained from the patient for publication of this case report. A copy of the written consent may be requested for review from the corresponding author.

Open Access This article is distributed under the terms of the Creative Commons Attribution-NonCommercial 4.0 International License (http://creativecommons.org/licenses/by-nc/4.0/), which permits any noncommercial use, distribution, and reproduction in any medium, provided you give appropriate credit to the original author(s) and the source, provide a link to the Creative Commons license, and indicate if changes were made.

\section{References}

1. Menter A, Korman NJ, Elmets CA, Feldman SR, Gelfand JM, Gordon KB, Gottlieb A, Koo JY, Lebwohl M, Leonardi CL, Lim HW. Guidelines of care for the management of psoriasis and psoriatic arthritis: section 6. Guidelines of care for the treatment of psoriasis and psoriatic arthritis: case-based presentations and evidence-based conclusions. J Am Acad Dermatol. 2011;65(1):137-74.
2. Leonardi CL, Kimball AB, Papp KA, Yeilding N, Guzzo C, Wang Y, Li S, Dooley LT, Gordon KB, PHOENIX 1 Study Investigators. Efficacy and safety of ustekinumab, a human interleukin-12/23 monoclonal antibody, in patients with psoriasis: 76-week results from a randomised, double-blind, placebo-controlled trial (PHOENIX 1). Lancet. 2008;371(9625):1665-74.

3. Papp KA, Langley RG, Lebwohl M, Krueger GG, Szapary P, Yeilding N, Guzzo C, Hsu MC, Wang Y, Li S, Dooley LT. Efficacy and safety of ustekinumab, a human interleukin-12/23 monoclonal antibody, in patients with psoriasis: 52-week results from a randomised, double-blind, placebo-controlled trial (PHOENIX 2). Lancet. 2008;371(9625):1675-84.

4. Chaplin S, Downs T. Ustekinumab: new option for moderate-tosevere psoriasis. Prescriber. 2009;20(21):29-32.

5. Tridente G. Ustekinumab. In: Tridente G, editor. Adverse events with biomedicines. Milan: Springer; 2014. p. 409-22.

6. Lovy MR, Starkebaum G, Uberoi S. Hepatitis C infection presenting with rheumatic manifestations: a mimic of rheumatoid arthritis. J Rheumatol. 1996;23(6):979-83.

7. Rachakonda TD, Schupp CW, Armstrong AW. Psoriasis prevalence among adults in the United States. J Am Acad Dermatol. 2014;70(3):512-6.

8. Parisi R, Symmons DP, Griffiths CE, Ashcroft DM. Global epidemiology of psoriasis: a systematic review of incidence and prevalence. J Invest Dermatol. 2013;133(2):377-85.

9. Duvic M, Asano AT, Hager C, Mays S. The pathogenesis of psoriasis and the mechanism of action of tazarotene. J Am Acad Dermatol. 1998;39(4 Pt 2):S129-33.

10. Morais MR, Meneghello LP, de Oliveira CF, Carvalho AV. Late reaction to ustekinumab infusion. Dermatol Rep. 2013;5(1):e2.

11. Youn SW, Tsai TF, Theng C, Choon SE, Wiryadi BE, Pires A, Tan W, Lee MG, MARCOPOLO Investigators. The MARCOPOLO study of ustekinumab utilization and efficacy in a realworld setting: treatment of patients with plaque psoriasis in AsiaPacific countries. Ann Dermatol. 2016;28(2):222-31.

12. Kanazawa K, Yaoita H, Tsuda F, Okamoto H. Hepatitis C virus infection in patients with urticaria. J Am Acad Dermatol. 1996;35(2):195-8.

13. Taglione E, Vatteroni ML, Martini P, Galluzzo E, Lombardini F, Delle Sedie A, Bendinelli M, Pasero G, Bencivelli W, Riente L. Hepatitis $\mathrm{C}$ virus infection: prevalence in psoriasis and psoriatic arthritis. J Rheumatol. 1999;26(2):370-2.

14. Yamamoto T, Katayama I, Nishioka K. Psoriasis and hepatitis C virus. Acta Derm Venereol. 1995;75(6):482-3.

15. Chouela E, Abeldano A, Panetta J, Ducard M, Negeia V, Sookoian S, Kina M, Castano G, Vereytou F, Frider B. Hepatitis C virus antibody (anti-HCV): prevalence in psoriasis. Int $\mathrm{J}$ Dermatol. 1996;35(11):797-9. 